Article Type: Research Paper

\title{
Corporate Governance Strength, Firm's Characteristics, and Islamic Social Report: Evidence from Jakarta Islamic Index
}

\author{
Wahyono $^{1}$, Eskasari Putri ${ }^{2}$, and Bayu Tri Cahya ${ }^{3 *}$
}

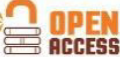

\section{AFFILIATION:}

1,2 Department of Accounting, Faculty of Economics and Business, Universitas Muhammadiyah Surakarta, Central Java, Indonesia.

${ }^{3}$ Department of Islamic Economics, Faculty of Islamic Economics and Business, Institut Agama Islam Negeri Kudus, Central Java, Indonesia.

\section{*CORRESPONDENCE:}

cahyab380@gmail.com

THIS ARTICLE IS AVAILABLE IN:

http://journal.umy.ac.id/index.php/ai

DOI: 10.18196/jai.2102155

\section{CITATION:}

Wahyono, Putri, E., \& Cahya, B. T. (2020). Islamic Social Report, Corporate Governance Strength, and Industry Characteristics on Jakarta Islamic Index. Journal of Accounting and Investment, 21(2), 383-400.

\section{ARTICLE HISTORY}

Received:

19 November 2019

Reviewed:

25 November 2019

1 April 2020

Revised:

3 December 2020

24 April 2020

Accepted:

13 May 2020

\begin{abstract}
:
Research aims: The purpose of this study is to analyze the effect of corporate governance strength, company size, profitability, company age, and industry type on Islamic social reports of Indonesian Companies that are listed in Jakarta Islamic Index.

Design/Methodology/Approach: The type of data used in this study was secondary data in the form of quantitative data, which included annual financial statements data completed with auditor's reports from each company listen on JII, especially in 2015-2017. The sampling method used in the study was purposive sampling.

Research findings: The results of data processed employing multiple regression test showed that company size, company age, and type of industry had a significant effect on the disclosure of Islamic social reporting. Corporate social strength and profitability had no significant effect on disclosure of Islamic social reporting.

Theoretical contribution/Originality: This research has theoretical implications in terms of developing knowledge and confirming theories about Islamic social reporting in Indonesia

Practitioner/Policy implications: This research can be used as a consideration for the company in policy making and as a basis for the company in decision making.

Research limitation/Implication: The study' results are expected to be a consideration in determining policies related to Islamic social reporting, especially law enforcement.

Keywords: Corporate Governance Strength, Firm's Characteristics; Islamic Social Report; Jakarta Islamic Index
\end{abstract}

\section{Introduction}

For the last few years, Corporate Social Responsibility (CSR) has become one of the critical issues in the business. One of the factors that push the issue is the importance of synergy between stockholders and stakeholders with a company (Yusuf, 2017). Besides, nowadays, a business entity has to adapt to its environment culturally (Daniri, 2006). These are to increase the company's awareness about the company's sustainability that depends on company's relationship with peoples and the environment in which the company operates its business (Umbara \& Suryanwa, 2014). 
Islamic Social Report, Corporate Governance Strength, and Industry Characteristics ...

The application of CSR voluntarily at the level beyond compliance gives opportunities for a company to increase its competitiveness and as a part of risk management towards company's sustainability (Kartini, 2013). Shortly, CSR means that a company should develop ethical and sustainable business practices economically, socially, and environmentally friendly.

In Islamic Economy, CSR is close to the activity performed by a company that is operated based on sharia. Today, most sharia companies use Global Reporting Initiative Index (GRII) to measure CSR disclosure as a reference (Haniffa, 2002; Jannah, \& Muid, 2014; \& Nawaiseh, Boa, \& El-shohnah, 2015). Actually, nowadays, besides GRII, there is an Islamic Social Reporting Index (ISR) that is interesting to be deeply discussed.

Sulaiman and Willet (2003), Zubairu, Sakariyau, and Dauda, C. K. (2011) emphasize that in the Islamic perspective, there are two points to be disclosed in a report: full disclosure and social accountability (Sulaiman \& Willet, 2003). From the Islamic point of view, public society has the right to access information of entity activities to some extent. One of the methods to achieve it is by applying ISR (Othman, Thani \& Ghani, 2009).

The application of ISR is expected to accommodate and produce accounting concepts and practices that comply with Islamic law, thus creating honest and fair practice. Therefore, by preparing the concept of social accountability concerning the principle of disclosure, it will be fulfilled the public need for information or disclosure based on Sharia principles.

The ISR concept was first raised by the Haniffa (2002), later developed by Othman et al. (2009), specifically in Malaysia. The ISR index is the benchmark of the implementation of sharia banking social activity that contains a compilation of standard CSR items stipulated by AAOIFI (Accounting and Auditing Organization for Islamic Financial Institutions). The items are then modified to match what is developed by an Islamic entity in the implementation of its operations, social activities, and reporting.

The ISR concept is in the form of the righteousness of humankind to Allah SWT, in the company's dimension. Siwar and Hossain (2009), in their research, concluded that Islamic values have a relevant relationship and contribute to the social report concept that has evolved to the present. In this case, ethics and social responsibility cannot be separated into a variety of muamalat activities.

Some previous studies related to ISR disclosure or Corporate Governance (CG) were conducted by Othman, et al. (2009), Othman and Thani (2010), Sofyani, Ulum, Syam, and Wahyuni (2012), Lestari (2013), Cahya (2017), Hasanah, Widiyanti, and Sudarno (2017), Sulistyawati and Yuliani (2017), and Santoso Ningsing, and Paramitha (2018).

Othman's research (2009) showed that the ISR was influenced by company size, profitability, and board composition. Another Othman's research (2010) showed that the ISR disclosure index was still considered to be minimally related to the points that had to be disclosed, so it showed a lack of transparency in the ISR disclosure. Research 
Islamic Social Report, Corporate Governance Strength, and Industry Characteristics ...

by Sofyani et al. (2012) showed that sharia banking performance in Malaysia had a higher social train average performance value than in Indonesia during the year 20092010. While, Lestari (2013) concluded that the company size and profitability had a significant effect on the ISR disclosure. Furthermore, the study of Cahya (2017) indicated that Corporate Governance Strength and profitability positively affected the ISR disclosure. Further research by Hasanah Widiyanti, and Sudarno (2017) also showed that the size of audit committees, liquidity, and profitability had a significant effect on the evacuation of ISR disclosure.

Sulistyawati and Yuliani's research (2017) concluded that the size of the independent Board of Directors affected the ISR disclosure. Finally, the results of the study by Santoso et al. (2018) indicated that the company size, Board Size, company age, profitability, partial public ownership, and company growth had a significant effect on the ISR disclosure.

Based on those studies, the research on the ISR disclosure has to develop by adding a variable of Corporate Governance Strength. The corporate governance strength factor is an important aspect to be reviewed, as researchers assume that corporate governance strength will be more likely to direct the quality of reporting. Besides, this variable is still quite rarely used by earlier researchers as variables that affect the ISR disclosure, so this research becomes necessary to do.

The results of this research, on the one hand, will contribute to the development of knowledge and confirm the theory about Islamic social reporting in Indonesia. On the other hand, it is also a consideration for determining company policies and as a base in decision making by corporate management. Finally, the study results can be considered in policy determination related to Islamic social reporting, especially law enforcement.

\section{Literature Review and Hypotheses Development}

\section{The stakeholder theory}

The stakeholder theory says that a company's existence is heavily influenced by its stakeholders' support (Chariri \& Ghozali, 2007). Gray, Kouhy, and Lavers (1995) state that business responsibilities to be accountable towards all stakeholders include corporate social and environmental responsibilities. The stakeholder theory aims to create value-added for stakeholders because the company's sustainability is supported by stakeholders. Therefore, the stakeholders need to be well managed so that the company supported by stakeholders, and objectives of the company can be achieved. Reporting on the environment plays a vital role in avoiding any actions by stakeholders that harm the company. The stakeholder theory identifies and models stakeholders in a company, as well as describes and recommends methods so that management can reward the interested owners. 
Islamic Social Report, Corporate Governance Strength, and Industry Characteristics ...

In relation to this research, stakeholders need information about the social responsibility that the company does. Therefore, disclosure is required by the company's social responsibility practices. The company may disclose the annual report. Stakeholders have the right to know all information, both mandatory and voluntary, as well as financial and non-financial information. Therefore, the company does not only aim to fulfill the interests and needs of the company itself but also should be able to provide benefits for stakeholders (the theory of stakeholders) (Purwanto, 2011).

\section{Legitimacy theory}

The theory of legitimacy can be understood from Lindblom's statement stating, "legitimacy is a condition where the value of a company is aligned with the social value system in which the company resides. When there is a difference between the two system values, a threat to the legitimacy of the entity is present" (Lindblom, 1994). This theory of legitimacy also relates to social disclosure. This theory suggests that companies express their legitimacy as they operate in the community area. Failure to disclose legitimacy can lead to adverse implications for the company (Zubairu et al., 2011). This theory encourages companies to ensure that their activities and performance are acceptable to the public. If the community is not satisfied with the legitimacy of operations, it can revoke social contracts (Deegan, Rankin, \& Tobin, 2002).

The public's expectations of corporate behavior can be "implicitly" and "explicitly" (Deegan, Rankin, \& Voght, 2000). The explicit form of social contracts is a legal requirement, while the implicit form is the hope of society that is not included in the expectations of the uncodified society (Dowling \& Pfeffer, 1975). Thus, legitimacy can be regarded as a potential benefit or source for the company to survive ( $O^{\prime}$ donovan, 2002).

The legitimacy theory encourages the company to undertake the responsibility of the environment to be seen as legitimate in the community. The company will tend to act according to the community's wishes, which can be responsible for the environment. The threat of the legitimacy of a company will encourage companies to include more social responsibility information in the annual report. However, in fact, many companies make such disclosures to gain legitimacy from society so that the company is seen as capable of fulfilling its social responsibilities. The failure of an organization or company in fulfilling the expectations of society will result in the organization or company being sanctioned by the community, in the form of restrictions on the legality of organizational or corporate operations, restrictions on access to resources, such as financial and labor capital, and the reduced consumption of company's product (Suwaldiman, 2013)

\section{Islamic Social Reporting}

Siwar and Hossain (2009) state that the basic foundations of the Islamic religion are Aqidah (belief and faith), Ibadah (worship), and Akhlaq (morality and ethics). In the economy, the main cornerstone is accountability, and one form of accountability in the perspective of Islamic economics is the reporting of corporate social responsibility following Sharia principles. From the Islamic perspective, the social report is a business 
Islamic Social Report, Corporate Governance Strength, and Industry Characteristics ...

practice that has Islamic ethical responsibilities. According to AAOIFI, ISR is all activities conducted by Islamic financial institutions to fulfill the interests of religious, economic, legal, ethical, and discretionary responsibilities as intermediary financial institutions for individuals and institutions.

The ISR Sharia framework was first triggered by Haniffa (2002). Ross states that there are many limitations to conventional social reporting. These sharia frameworks are the basis for the development of material, moral, and spiritual aspects of the company's ISR reporting. It was further developed by Rohana Othman et al. (2009) in Malaysia, and continued to be developed by subsequent researchers. The main foundation of the sharia framework is Tauhid (QS. Thaha: 53-54). The consequence of the Tauhid is the obligation to submit to all the laws of Allah SWT sourced from the Qur'an, Hadith, Figh, and other sources, such as Qias, ljtihad, and ljma. The purpose of this sharia law is to uphold social justice and to reach the world and the hereafter (Al Falah) (Haniffa, 2002). Then, this Sharia law will be the basis of the concept of ethics in Islam. This ethics then becomes the foundation of human beings in conducting political, economic, and social activities. The ISR is in the sphere of economic activity, particularly accounting aspects. Thus, the ISR is part of the sharia framework.

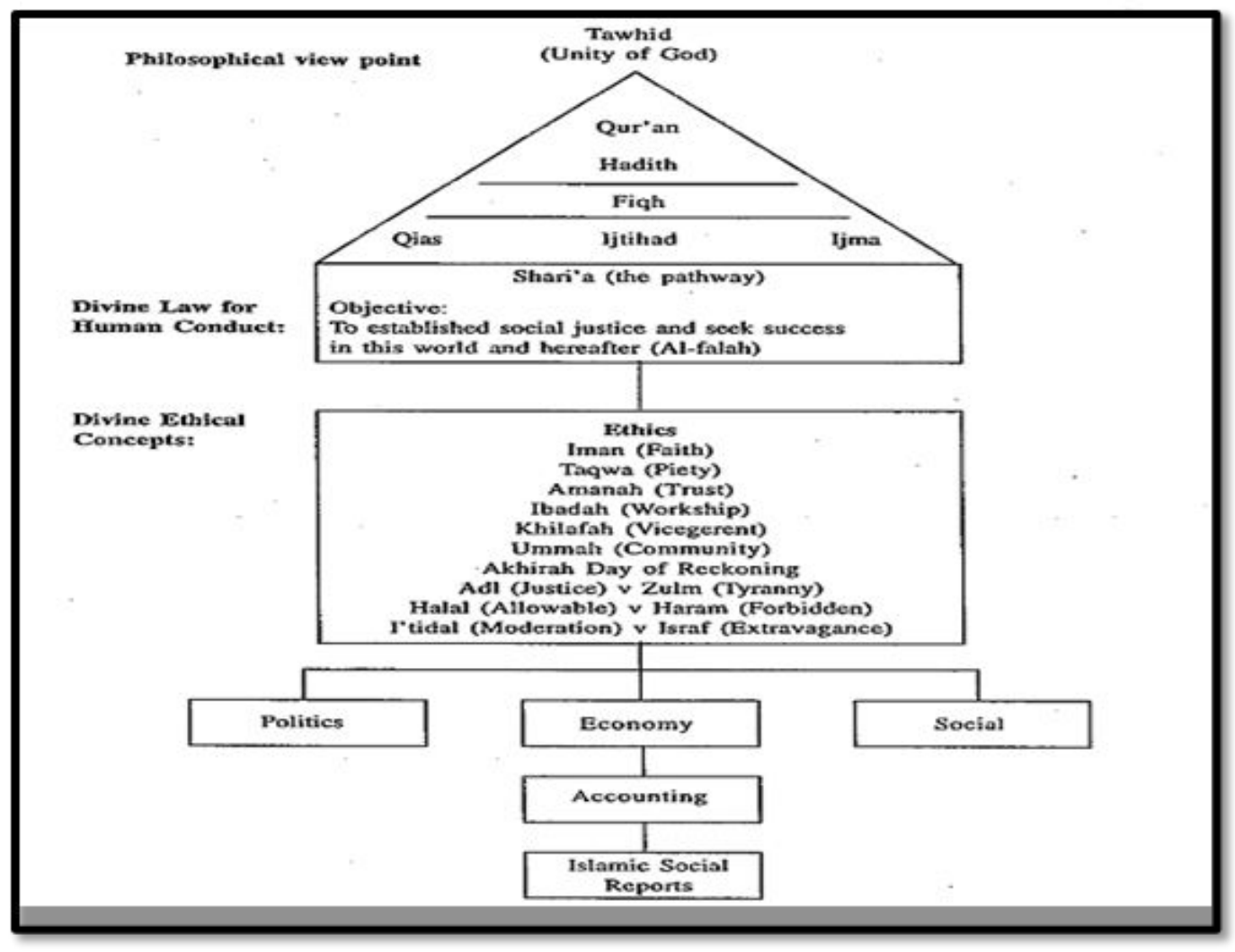

The ISR index creates five of the ISR index disclosure themes, namely funding and investment themes, product and service themes, employee themes, community themes, environmental themes, and corporate governance themes (Haniffa, 2002). Then, Othman et al. (2009) developed it, adding one theme, namely disclosure. 
Islamic Social Report, Corporate Governance Strength, and Industry Characteristics ...

Some previous research related to Islamic Social Reporting research topics are as follows: Santoso et al. (2018) wrote that company size, Board size, company age, profitability, partial public ownership, and company growth had a significant effect on the company's ISR disclosure in JII. Cahya, Nuruddin, Ikhsan (2017), in their research, stated that Corporate Governance Strength and profitability had a positive effect on the ISR disclosure. However, company size had a significant negative effect on the ISR disclosure, while media exposure had no significant effect on ISR disclosure. The research also showed that the relationship between corporate governance strength, company size, and profitability to company value was mediated by ISR disclosure. Hasanah Widiyanti, and Sudarno (2017) stated that the size of audit committees, liquidity, and profitability had a significant effect on the ISR disclosure, while the size of the board of directors and leverage did not affect the ISR disclosure. Sulistyawati and Yuliani (2017) stated that the independent board of directors' size partially had a significant positive effect on the ISR disclosure, while company size, profitability, and leverage, partially had no positive effect on the ISR disclosure.

Safarina (2016) stated that in her literature studies between 2000-2014, it showed that the evolution of social and Islamic environments reporting was poorly structured. Earlier researchers gave more attention to Islamic financial institutions than other companies/industries. Recent studies have been focused on descriptive analysis and empirical trying to prove the index developed by previous researchers. Researchers suggest that subsequent research should be more aimed at exploraing the other concept of social reporting in accordance with Sharia guidelines. Indrawaty and Wardayati (2016) asserted that the Islamic Corporate Governance is determined by the existence and composition of the membership of sharia supervisory board, size and composition of the board of directors, frequency of board of directors' meeting, size and composition of the audit committee, and the number of audit committee meetings.

The analysis of Saridona and Cahyandito (2015) showed that the social performance of Indonesian sharia banks, revealed in the annual report 2013, was in the 'good' category. Social performance in this study was based on the Islamic social index reporting. In general, CSR activities conducted by Islamic-based banks in Indonesia have focused on social activities, including assistance to the specific community, educational programs such as the improvement of educational equipment, and also health care. Unfortunately, few of these banks have a concern for environmental sustainability.

Wan Abdullah, Percy, and Stewart (2014) stated in their article that the level of CG disclosure on sharia banks in the annual report was less than 50 percent. Besides, voluntary CG disclosure was also negatively related to the level of political and civil repression, but the size and state code of the law were positively associated with voluntary CG disclosure. Sofyani (2014) stated that the highest Islamic social banking activity was in Malaysia, the second was in Indonesia, and the lowest was in Saudi Arabia. Umbara and Suryanawa (2014) wrote that CSR disclosures had a positive effect on the company's value; CSR disclosure positively affected the value of the company categorized as a high profile company and low profile company. Jannah and Muid stated 
Islamic Social Report, Corporate Governance Strength, and Industry Characteristics ...

that media exposure, industrial type, profitability, company size, and leverage affected the company's carbon emissions disclosure in Indonesia.

Khoirudin (2013) affirmed that the size of the Board of Directors had a positive influence on the ISR disclosure on Sharia banking in Indonesia. While, the size of the sharia supervisory board was not proven to affect the ISR disclosure on Sharia banking in Indonesia. Lestari (2013) stated that the company size and profitability level had a significant effect on the ISR disclosure level, but on the contrary, the company's age and the proportion of independent commissioners had no significant effect on the ISR disclosure level. Ayu and Siswantoro (2013) found that the type of industry and profitability did not affect the rate of ISR disclosure. Meanwhile, the factor that affected the ISR disclosure rate was only the company size. These factors had a significant positive influence on the rate of ISR disclosure. Ahzar and Trisnawati (2013) stated that Bank Mega Syariah and BRI Syariah received the highest score in the disclosure of social responsibility, while the lowest result was at Bank Bukopin Syariah. The form of social responsibility activities conducted by sharia banks in Indonesia focuses on the social activities of channeling corporate zakat to a number of zakat institutions, providing social assistance to poor people, providing assistance to education, providing assistance to disaster victims, and providing health assistance.

Sofyani et al. (2012) said that the social train-average performance of Islamic banking in Malaysia was higher than in Indonesia. Othman, and Thani (2010) affirmed that the ISRlevel disclosure index was considered minimal, indicating a lack of transparency in disclosure concerning Islamic values, although the concept of social accountability under Islam is related to the principle of full disclosure. Research by Myring, and Shortridge (2010) stated that the company's strengths could be identified by the impact of corporate governance on the quality of financial reporting information. Fitria and Hartanti (2010) stated that conventional banking institutions generally received higher scores than sharia banking institutions. Othman et al. (2009) asserted that the board's size, profitability, and composition significantly affected company's provision of Islamic social reporting.

\section{Hypothesis Development}

\section{The Influence of Corporate Governance to the Islamic Social Report}

Wan Abdullah's research (2013) on CG disclosure practices on Islamic Banks in Southeast Asian countries and the Gulf Cooperation Council region revealed that the CG elements and the characteristics of the Shariah Supervisory Board were positively related to the voluntary disclosure of CG. Likewise, the research of Khoirudin (2013) stated that the size of the Board of Commissioners, which is one of the CG elements, had a positive influence on the disclosure of Islamic social report on sharia banking in Indonesia.

$H_{1}$ : Corporate Governance affects Islamic Social Report 
Islamic Social Report, Corporate Governance Strength, and Industry Characteristics ...

\section{The Influence of Company Size to Islamic Social Report}

Othman et al. (2009) concluded that the characteristics of the company represented by the company size, profitability, and board of directors affected the ISR disclosure. Likewise, the research of Ayu and Siswantoro (2013) showed that the company's size affected the ISR disclosure. This research proves that larger companies tend to reveal ISR more broadly than smaller companies.

Those findings are in accordance with the stakeholders' theory stating that large corporations usually have more and more complex activities, a more significant impact on society, more shareholders, and more attention from the public. That way, large companies get more pressure to express their social responsibility.

$\mathrm{H}_{2}$ : Company size affects the Islamic Social Report.

\section{The Impact of Profitability on Islamic Social Report}

Choi, Lee, and Psaros (2013) state that companies with good financial conditions can pay the human or financial resources needed for better voluntary reporting to withstand external pressures. The research of Widiawati and Raharja (2012) proves that companies in favorable positions will tend to reveal wider ISR than companies that suffer losses, although not overall, the losing company will reveal smaller ISR. Based on that, it can be indicated that the higher the profitability, the broader the information disclosure is done, including information about Islamic social responsibility.

$H_{3}$ : Profitability affects Islamic Social Report.

\section{The Influence of Company Age on Islamic Social Report}

A study by Anggreni and Budiasih. (2016) revealed that the company's age had a significant effect on the market reaction in terms of CSR disclosure. The company's age is closely related to how the company will pass on its information (Lestari 2013). A company with an older age has the possibility of revealing a more complete information because of their experience as well as their demands to maintain its image in the community. However, if a company has a relatively young age, then the company will tend to focus more on gaining profit so that it will provide standard information. Thus, a company with an older age is expected to present more complete CSR disclosure information.

$H_{4}$ : Company age affects Islamic Social Report. 
Islamic Social Report, Corporate Governance Strength, and Industry Characteristics ...

\section{The Influence of Industrial Type on Islamic Social Report}

The research by Purwanto (2011) concluded that industrial type and company size significantly affected social responsibility disclosures. Companies with high profile categories reveal better social responsibility. The research by Widiawati and Raharja (2012) stated that the company size, profitability, industry type, and business type significantly and positively affected the ISR disclosure

$H_{5}:$ Industry type affects the Islamic Social Report

\section{Theoretical framework}

Based on the studies explained, a theoretical framework can be constructed as follows:

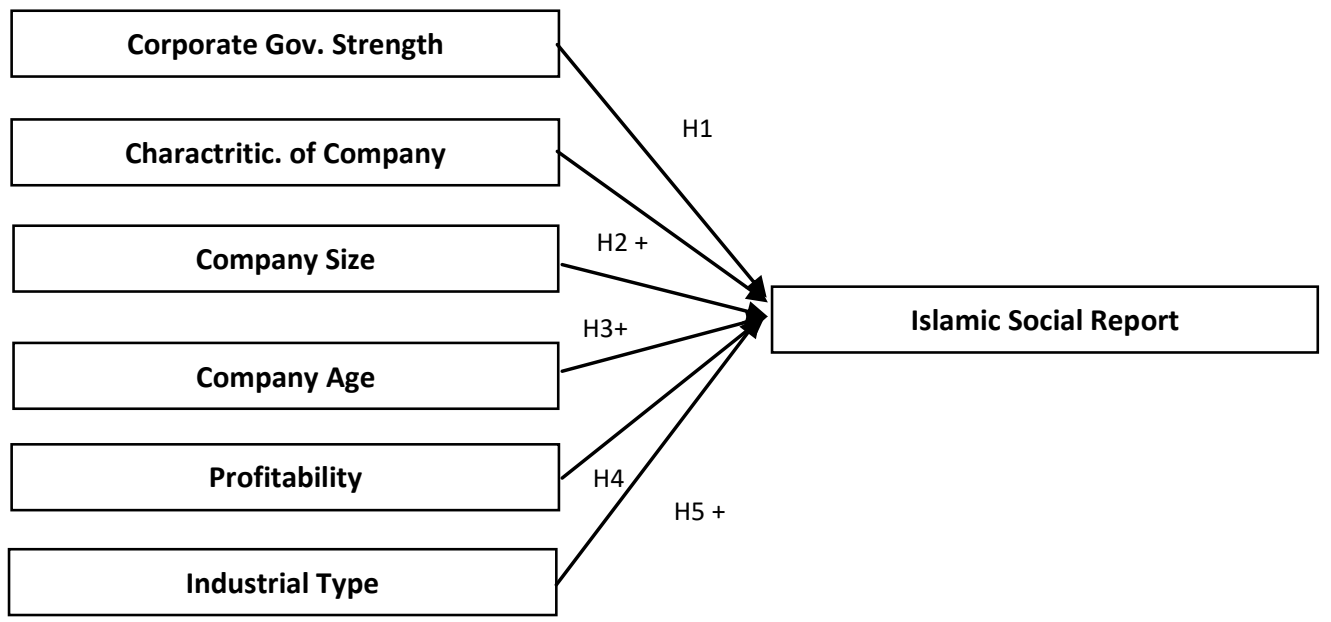

\section{Research Method}

\section{Results of data analysis}

The data used in this research was secondary data amounting to 90 banks, which was obtained from the annual report listed in IDX (Indonesia Stock Exchange) in the period 2015 - 2017. The data were also collected from related sites that published related financial statements, such as www.idx.co.id and the Indonesian Capital Market Directory (ICMD). Basically, samples in this research were listed companies in Jakarta Islamic with the following criteria:

a. Companies were listed on JII for one year or in the current period of reporting.

b. The company has issued a full annual report and was presented in rupiah currency for the period ended 31 December.

c. Companies did not de-listing during the year of research. 
Islamic Social Report, Corporate Governance Strength, and Industry Characteristics ...

The variables in this study included dependent and independent variables. The following is the identification and measurement of the variable:

\begin{tabular}{|c|c|c|c|}
\hline Variables & Operational definition & Indicators & References \\
\hline$I S R$ & $\begin{array}{l}\text { Corporate social activity } \\
\text { reporting by using the } \\
\text { material, social, and } \\
\text { spiritual dimension }\end{array}$ & $\begin{array}{l}\text { Measured using indices based on } \\
\text { aspects: financing and investment, } \\
\text { products and services, employees, } \\
\text { society, environment and corporate } \\
\text { governance }\end{array}$ & $\begin{array}{l}\text { Bayu Tri Cahya, Amiur } \\
\text { Nuruddin, and Arfan } \\
\text { Iksan (2017) }\end{array}$ \\
\hline $\begin{array}{l}\text { Corporate } \\
\text { Governance } \\
\text { Strength }\end{array}$ & $\begin{array}{l}\text { The CG power of its } \\
\text { components includes } \\
\text { the board size, } \\
\text { Committee audit, and } \\
\text { the independence Chair }\end{array}$ & $\begin{array}{l}\text { Measured using board size } \\
\text { composition, Committee audit, and } \\
\text { independence Chair }\end{array}$ & $\begin{array}{l}\text { Safarina (2016) } \\
\text { Sofyani, Hafiez (2014) }\end{array}$ \\
\hline Company Size & $\begin{array}{l}\text { The magnitude of a } \\
\text { company measured by } \\
\text { the number of company } \\
\text { assets }\end{array}$ & $\begin{array}{l}\text { The magnitude of a company } \\
\text { measured by the logarithm of total } \\
\text { assets }\end{array}$ & $\begin{array}{l}\text { Resa Saridona and } \\
\text { Martha Fani } \\
\text { Cahyandito } \\
\text { (2015) }\end{array}$ \\
\hline Profitability & $\begin{array}{l}\text { Management } \\
\text { performance indicators } \\
\text { in managing the } \\
\text { company's wealth } \\
\text { demonstrated by profit } \\
\text { generated }\end{array}$ & Earning Before Tax & $\begin{array}{l}\text { Wan Amalina Wan } \\
\text { Abdullah, Majella } \\
\text { Percy and Jenny } \\
\text { Stewart (2014) }\end{array}$ \\
\hline Company Age & $\begin{array}{l}\text { The duration of the } \\
\text { company listed in the } \\
\text { stock market }\end{array}$ & $\begin{array}{l}\text { Measured by calculating the } \\
\text { company when the company is } \\
\text { registered in IDX until current } \\
\text { research }\end{array}$ & $\begin{array}{l}\text { Indrawaty and Siti } \\
\text { Maria Wardayati } \\
\text { (2016). }\end{array}$ \\
\hline $\begin{array}{l}\text { Type of } \\
\text { Industry }\end{array}$ & $\begin{array}{l}\text { Classification of } \\
\text { business based on its } \\
\text { product }\end{array}$ & $\begin{array}{l}\text { Measured by classifying } \\
\text { manufacturing and non- } \\
\text { manufacturing companies }\end{array}$ & $\begin{array}{l}\text { Jannah, Richatul, and } \\
\text { Dul Muid (2013) }\end{array}$ \\
\hline
\end{tabular}

The analysis used to test the relationships of some independent variables against dependent variables was multiple regression tests. Before a multiple regression test was performed, the data processed had passed the classic assumption test

The equation of regression to test the proposed hypotheses is expressed in the following models:

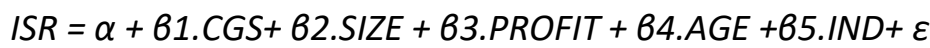

Note:

$\begin{array}{ll}\text { ISR } & =\text { Islamic Social Report } \\ \text { CGS } & =\text { Corporate Governance Strength } \\ \text { SIZE } & =\text { Company size } \\ \text { PROFIT } & =\text { Profitability } \\ \text { AGE } & =\text { Company age } \\ \text { IND } & =\text { Type of industry } \\ \alpha & =\text { Constanta } \\ \beta & =\text { Coefficient } \\ \varepsilon & =\text { Error term }\end{array}$


Islamic Social Report, Corporate Governance Strength, and Industry Characteristics ...

\section{Results and Discussion}

Based on the One-Sample Kolmogorov-Smirnov test, it showed the number of 0.908 with a significance level of 0.05 so that it can be concluded that the entire data were distributed normally. A multicollinearity test was performed by looking at the value of tolerance and variance inflation factor (VIF). The results of the multicollinearity test were GCG: 1.435; SIZE: 1.611; PROFIT: 3.371; AGE: 3.349; and IND: 1.281. Because all independent variables had a tolerance value of $>0.1$ and a VIF of $<10$, it can be concluded that the data were free from multicollinearity. The test of heteroscedasticity was conducted with the Glacier-test. The results of the heteroscedasticity test showed that the value of CGS: 0.391; SIZE: 0.524; PROFIT: 0.429; AGE: 0.694, and IND: 0.236. It means that each variable had a significant value higher than 0.05 , so data were free from heteroscedasticity. To test the existence of autocorrelation, the theory of Durbin Watson was employed, and the result showed a significant value of DW of 1.260. The significant value of DW on these regression models was $>-2$ and $<2$. Thus, it can be inferred that there was no autocorrelation.

\section{Results of Multiple Linear Regression Data Analysis}

\begin{tabular}{|c|c|c|}
\hline Hypothesis Testing & & Results \\
\hline Coefficient of determination test (Adjusted $R^{2}$ ) & 0.294 & \\
\hline \multicolumn{3}{|l|}{ Significant Simultaneous F-test } \\
\hline $\mathrm{F}$ & 4.159 & \\
\hline Sig. & 0.005 & \\
\hline \multicolumn{3}{|l|}{ Significant Partial test (t-test) } \\
\hline \multirow[t]{5}{*}{ Standard-errors coefficient } & CGS & -0.015 \\
\hline & SIZE & 0.039 \\
\hline & PROFIT & 0.000 \\
\hline & AGE & -0.003 \\
\hline & IND & 0.049 \\
\hline \multirow[t]{5}{*}{$\mathrm{t}$} & CGS & -0.426 \\
\hline & SIZE & 2.220 \\
\hline & PROFIT & 0.026 \\
\hline & AGE & -2.513 \\
\hline & IND & 1.990 \\
\hline \multirow[t]{5}{*}{ Sig. } & CGS & 0.673 \\
\hline & SIZE & $0.033^{* *}$ \\
\hline & PROFIT & 0.980 \\
\hline & AGE & $0.017^{* *}$ \\
\hline & IND & $0.055^{* * *}$ \\
\hline \multirow[t]{5}{*}{ Conclusion } & CGS & Rejected \\
\hline & SIZE & Accepted \\
\hline & PROFIT & Rejected \\
\hline & AGE & Accepted \\
\hline & IND & Accepted \\
\hline
\end{tabular}




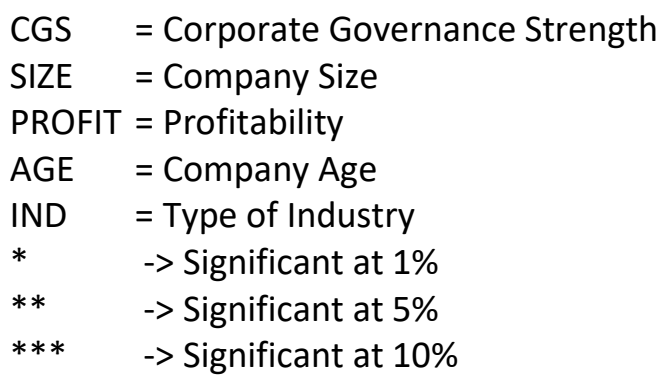

Based on the multiple linear regression equation, it can be interpreted as follows. The value of constants was 0.053 , meaning that if the value of variables corporate governance strength, company size, profitability, company age, and industrial type, were zero, then the value of the variable Islamic Social Report would remain at 0.053 . The value of the CGS coefficient of -0.015 indicates that if the CGS variable were increased by 1 point, the ISR variable value would decrease by 0.015 points. The value of the coefficient of SIZE of 0.039 means that if the SIZE variable raised by 1 point, the ISR variable value would increase by 0.039 points. The value of PROFIT coefficient was 0.00000000004125 , indicating that if the PROFIT variable rose by 1 point, the value of the ISR variable would increase by 0.00000000004125 points. The AGE coefficient value of -0.003 indicates that if the AGE variable rose by 1 point, the ISR variable value would decrease by- 0.003 points. Also, the IND coefficient value was 0.049 , meaning that if the IND variable increased by 1 point, the ISR variable value would rise by 0.049 points.

The test of the coefficient of determination resulted in the adjusted value of R2 as $29.4 \%$. It indicates that as many as $29.4 \%$ of the ISR disclosure was explained by the variation of five independent variables used, while the remaining, $70.6 \%$, was explained by other factors outside of this study.

Furthermore, the results F-test showed that the $F$ value of 4.159 was significant at 0.005 , which was smaller than 0.05 . It means that the regression model could be used to predict the independent variables used in this variable that collectively affected the ISR disclosure.

The t-test result indicates that several independent variables affected the dependent variable, including company size, company age, and industry's type. While, the corporate governance strength and profitability had no effect on ISR disclosure.

The results of multiple regression analyses showed that variables of company size, company age, and type of industry had $t$-value $>t$ table, as well as its significant value. Hence, hypotheses 2,4 , and 5 were accepted.

\section{Discussion}

This research proves that the power of corporate governance (CGS) does not have a significant influence on the ISR disclosure. It is in line with Khoirudin (2013) research, which stated that the power of corporate governance did not affect ISR disclosure. 
Islamic Social Report, Corporate Governance Strength, and Industry Characteristics ...

Based on the results, it can be interpreted that the components that support the strength of corporate governance, among them, is the Sharia supervisory board, paying less attention to the ISR disclosure.

Furthermore, the size of the company had a significant positive influence on the ISR disclosure. It means that large corporations are more likely to disclose content related to Islamic social reporting to attract or increase investors' trust. The findings are consistent with the research conducted by Ebiringa, Yadirichukwu, and Chigbu (2013), Nawaiseh et al. (2015), Dibia and Onwuchekwa (2015). In general, the larger the size of the company, the more information available to investors in the decision making in connection with their investments in the company.

The variable of age companies also demonstrates that there was a significant positive influence on the ISR disclosure. This result indicates that the older the company, the more experience the company in its operation and earning profit achieve the company objective. As a result, the company has a broader opportunity to convey more comprehensive information to stakeholders, which are expected to improve its image. The results of this study were consistent with the research of Widiyanti and Hasanah (2017).

Profitability had no significant effect on the ISR disclosure. It means that the level of profitability does not reflect the ability of the entity to enhance its social responsibility, including the disclosure of sharia-based social responsibility in the annual report. These results are actually quite rational because of the amount of profit the company gained, the disclosure of business activities, including the Islamic-based ones, must be done. The findings are in accordance with the research results of Ayu and Siswantoro (2013).

The industry-type variables had a significant positive influence on the ISR disclosure. It shows that increasingly diverse industries belong to manufacturing companies, and companies that have a type of marketable securities, then those companies reveal more of the ISR information more broadly. The research is in line with the research results of Widiawati and Raharja (2012).

\section{Conclusion}

This research proves that variable size enterprise, company age, and industry type affected the ISR disclosure. Meanwhile, the Corporate Governance Strength (CGS) variable and profitability had no significant effect on the ISR.

The results of this study are expected to contribute to the development of theories and knowledge of the ISR in Indonesia. Besides, it can be used as a consideration in making investment decisions because the disclosure of information relating to the ISR is one of the essential things for stakeholders who consider Shariah-compliant concepts. Moreover, the results of this study can be used as a consideration in determining the company policies and the basis of the need for disclosure of ISR in financial reporting, 
Islamic Social Report, Corporate Governance Strength, and Industry Characteristics ...

and in the end, can be a consideration in policy determination related to the ISR primarily related law enforcement.

The limitations of this study are the retrieval of secondary data on quantitative data, which includes the complete annual financial report data, and the auditor's report of each company listed in JII covering only two years in 2015-2017. The research will be more powerful if the period is expanded for more than two years to provide a more thorough picture.

\section{References}

Ahzar, F. A., \& Trisnawati, R. (2013). Pengungkapan Islamic Social Reporting Pada Bank Syariah di Indonesia. Proceeding Seminar Nasional Dan Call For Papers Sancall 2013, Surakarta. Retrieved from https: $/ / \mathrm{www} \cdot g o o g l e . c o m /$ url? $\mathrm{sa}=\mathrm{t} \& \mathrm{rct}=\mathrm{j} \& \mathrm{q}=\& \mathrm{esrc}=\mathrm{s} \&$ source $=\mathrm{web} \& \mathrm{~cd}=\& \mathrm{cad}=\mathrm{rj}$ a\&uact $=8 \& v e d=2$ ahUKEwil28vn1 fjpAhUXXn0KHVFaDnAQFjAAegQIAxAB\&u $\mathrm{rl}=\mathrm{https} \% 3 \mathrm{~A} \% 2 \mathrm{~F} \% 2 \mathrm{Fpublikasiilmiah.ums.ac.id} \% 2 \mathrm{Fbitstream} \% 2 \mathrm{Fhandle} \% 2 \mathrm{~F} 11617$ \%2F 3798\%2F 46.\%2520Fahri\%2520Ali\%2520Ahzar \%2520\%2526\%2520Rina \%252 0Trisnawati.pdf $\% 3$ Fsequence $\% 3$ D $1 \% 26$ is Allowed $\% 3$ Dy\&usg $=$ AOvVaw 3 S7FA43a G11ySwgbF5yVDh

Anggreni, N. L. P. M., \& Budiasih, I G. A. N. (2016). Peran Media Exposure Bagi Pasar Modal Indonesia. Jurnal Buletin Studi Ekonomi, 21(1), 60-70. Retrieved from https://ojs.unud.ac.id/index.php/bse/article/view/22299

Ayu, D. F., \& Siswantoro, D. (2013). Implikasi Proksi Aset, Profitabilitas dan Jenis Industri pada Islamic Social Reporting (ISR). Al-Muzara'ab, 1(1), 39-55. https://doi.org/10.29244/jam.1.1.39-55

Cahya, B. T. (2017). Carbon Emission Disclosure: Ditinjau dari Media Exposure, Kinerja Lingkungan dan Karakteristik Perusahaan Go Public Berbasis Syariah di Indonesia. Niz̧ham Journal of Islamic Studies, 4(2), 170-188. Retrieved from http://ejournal.metrouniv.ac.id/index.php/nizham/article/view/916

Cahya, B. T. (2017). Islamic Social Report: Ditinjau dari Aspek Corporate Governance Strength, Media Exposure dan Karakteristik Perusahaan Berbasis Syariah di Indonesia Serta Dampaknya Terhadap Nilai Perusahaan (Doctoral Dissertation, Pascasarjana UIN-SU).

Cahya, B. T., Nuruddin, A., \& Ikhsan, A. (2017). Islamic Social Reporting: From the Perspectives of Corporate Governance Strength, Media Exposure and the Characteristics of Sharia Based Companies in Indonesia and its Impact On Firm Value. IOSR Journal Of Humanities And Social Science (IOSR-JHSS). 22(5), 71-78. Retrieved from https://islamicmarkets.com/publications/islamic-social-reportingfrom-the-perspectives-of-corporate-governance-strength

Chariri, A., \& Ghozali, I. (2007). Teori Akuntansi. Semarang: Badan Penerbit Universitas Diponegoro.

Choi, B. B., Lee, D., \& Psaros, J. (2013). An analysis of Australian Company Carbon Emission Disclosures. Pacific Accounting Review, 25(1). Retrieved from https: / $/$ www.google.co.id $/$ url? sa $=t \& r c t=j \& q=\& e s r c=s \&$ source $=$ web\&cd $=\& c a d=r j$ a\&uact $=8$ \&ved $=2$ ahUKEwix1-C5I qAhWBYisKHc5DDDsQFjAAegQIBBAB\&url=https $\% 3 \mathrm{~A} \% 2 \mathrm{~F} \% 2 \mathrm{Fwww}$.researc 
hgate.net $\% 2$ Fpublication $\% 2 \mathrm{~F} 263501874$ An analysis of Australian company car bon emission disclosures\&usg=AOvVaw1P42x0kTrCKq2LhGZF1FRY

Daniri, M. A. (2008). Standarisasi Tanggung Jawab Sosial Perusabaan. Kadin Indonesia.

Deegan, C., Rankin, M., \& Tobin, J. (2002). An Examination of the Corporate Social and Environmental Disclosures of BHP from 1983-1997. Accounting, Auditing \& Accountability Journal. 15(3), 312-343. https://doi.org/10.1108/09513570210435861

Deegan, C., Rankin, M., \& Voght, P. (2000). Firms' disclosure reactions to major social incidents: Australian evidence. In Accounting forum. 24(1), 101-130. https://doi.org/10.1111/1467-6303.00031

Dibia, N. O. \& Onwuchekwa, J. C. (2015). Determinants of Environmental Disclosures in Nigeria:A Case Study of Oil and Gas Companies. International Journal of Finance and Accounting, 4(3), 145-152. Retrieved from http://article.sapub.org/10.5923.j.ijfa.20150403.01.html

Dowling, J., \& Pfeffer, J. (1975). Organizational legitimacy: Social Values and Organizational Behavior. Pacific sociological review, 18(1), 122-136. https://doi.org/10.2307/1388226

Ebiringa, O. T., Yadirichukwu, E., Chigbu, E. E., \& Ogochukwu, O. J. (2013). Effect of firm size and profitability on corporate social disclosures: The Nigerian oil and gas sector in focus. British Journal of Economics, Management \& Trade, 3(4), 563-574. https://doi.org/10.9734/bjemt/2013/5147

Fitria, S., \& Hartanti, D. (2010). Islam Dan Tanggung Jawab Sosial : Studi Perbandingan Pengungkapan Berdasarkan Global Reporting Initiative Indeks dan Islamic Social Reporting Indeks. Purwokerto: Simposium Nasional Akuntansi 13. Retrieved from http://pdeb.fe.ui.ac.id/?p=5083

Ghozali, I. (2013). Aplikasi Analisis Multivariate Dengan Program IBM SPSS 21 Update PLS Regresi. Semarang: Badan Penerbit Universitas Diponegoro.

Gray, R., Kouhy, R., \& Lavers, S. (1995). Corporate social and environmental reporting. Accounting, Auditing \& Accountability Journal. 8(2), 47-77. https://doi.org/10.1108/09513579510146996

Haniffa, R. (2002). Social Reporting Disclosure: An Islamic Perspective. Indonesian Management \& Accounting Research. 1(2): 128-146. Retrieved from https://www.scribd.com/doc/312550684/Haniffa-R-Social-Reporting-DisclosureAn-Islamic-Perspective-2002

Hasanah, N. T., \& Widiyanti, N. W., \& Sudarno. (2017). Analisis Pengaruh GCG dan Kinerja Terhadap Pengungkapan Islamic Social Reporting (ISR). E- Journal Ekonomi Bisnis dan Akuntansi, 5(2), 115-120. https://doi.org/10.19184/ejeba.v5i2.8645

Indrawaty \& Wardayati, S. M. (2016). Implementing Islamic Corporate Corporate Governance (ICG) and Islamic Social Report (ISR) in Islamic Financial Institution (IFI). Procedia-Social and Behavioral Sciences, 219, 338-343.

https://doi.org/10.1016/i.sbspro.2016.04.042

Jannah, R., \& Muid, D. (2014). Analisis Faktor-Faktor Yang Mempengaruhi Carbon Emission Disclosure Pada Perusahaan Di Indonesia (Studi Empiris Pada Perusahaan Yang Terdaftar Di Bursa Efek Indonesia Periode 2010-2012). Diponegoro Journal of Accounting, 3(2), 1000-1010. Retrieved from https:// ejournal3.undip.ac.id/index.php/accounting/article/view/6164

Kartini, D. (2013). CSR Tranformasi Konsep Sustainability Management dan Implementasi di Indonesia. Bandung: PT. Refika Aditama.

Khoirudin, A. (2013). Corporate Governance dan Pengungkapan Islamic Social Reporting Pada Perbankan Syariah di Indonesia. Accounting Analysis Joumal, 2(2). 227-232.

https://doi.org/10.15294/aaj.v2i2.2919 
Lestari, P .(2013). Determinants of Islamic Social Reporting In Syariah Banks: Case Of Indonesia, International Journal of Business and Management Invention, 2 (10), 2013, h. 28-34

Lindblom, C. K. (1994). The implications of organizational legitimacy for corporate social performance and disclosure. Conference Paper, Critical Perspectives on Accounting Conference, New York. Retrieved from https://www.scirp.org/(S(351jmbntvnsjt1aadkposzje))/reference/ReferencesPapers. aspx?ReferenceID $=1905311$

Myring, M., \& Shortridge, R. T. (2010). Corporate Governance And The Quality Of Financial Disclosures. International Business \& Economics Research Journal (IBER), 9(6). https://doi.org/10.19030/iber.v9i6.589

Nawaiseh, M. E., Boa, S. S. A., \& El-shohnah, R. A. Z. Y. (2015). Influence of firm size and profitability on corporate social responsibility disclosures by banking firms (CSRD): Evidence from Jordan. Journal of Applied Finance \& Banking, 5(6), 97-111. Retrieved from https://www.google.com/url?sa=t\&rct=j\&q=\&esrc=s\&source=web\&cd $=\& c a d=r j$ a\&uact $=8 \& v e d=2$ ahUKEwieiNXq6vipAhWbXSsKHf0ZBpcQFjAAegQIAxAB\&ur $\underline{\mathrm{l}=\mathrm{http} \% 3 \mathrm{~A} \% 2 \mathrm{~F} \% 2 \mathrm{Fwww} . \text { scienpress.com } \% 2 \mathrm{FUpload} \% 2 \mathrm{FJAFB} \% 2 \mathrm{FVol} \% 252056}$ 6.pdf\&usg=AOvVaw2z2EX4bU4QFoyJ228sGAIp

O'donovan, G. (2002). Environmental disclosures in the annual report. Accounting, Auditing \& Accountability Journal. 15(3), 344-371. https://doi.org/10.1108/09513570210435870

Othman, R., \& Thani, A. M. (2010). Islamic social reporting of listed companies in Malaysia. International Business \& Economics Research Journal (IBER), 9(4), 135-144. https://doi.org/10.19030/iber.v9i4.561

Othman, R., Thani, A. M., \& Ghani, E. K. (2009). Determinants of Islamic social reporting among top Shariah-approved companies in Bursa Malaysia. Research Journal of International Studies, 12(10), 4-20. Retrieved from https:/ $/$ www.google.com/url? sa $=$ t\&rct=j\&q $=\& e s r c=s \&$ source $=$ web\&cd $=\& c a d=r j$ a\&uact=8\&ved=2ahUKEwi6wZiv7PjpAhVN73MBHcIfDfsQFjAAegQIAxAB\&url $=$ http $\% 3 \mathrm{~A} \% 2 \mathrm{~F} \% 2$ Flela.stiemi.ac.id $\% 2$ Fwp-content $\% 2$ Fuploads $\% 2$ FIslamic-socialreporting-Kel6.pdf\&usg=AOvVaw1UTw Y-18jJeXZK7i5k-OU

Purwanto, A. (2011) Pengaruh Tipe Industri, Ukuran Perusahaan, Profitabilitas, Terhadap Corporate Social Responsibility. Jurnal Akuntansi \& Auditing, 8(1), 12-29. https://doi.org/10.14710/jaa.8.1.12-29

Safarina, B. A. G. (2016). The Development Of Islamic Social And Environmental Reporting. Journal of Education and Social Sciences, 4(June.), 258-261. Retrieved from https://www.jesoc.com/wp-content/uploads/2016/06/KC4 132.pdf

Santoso, N. T., Ningsih, R. M., \& Paramitha, R. P. (2018). Determinats of Islamic Social Repoting Disclosure: The Case of Jakarta Islamic Index. Spinger Nature Singapore. 2739. Retrieved from https: / $/$ www.google.co.id / url?sa $=t \& r c t=j \& q=\& e s r c=s \&$ source $=$ web\&cd $=\& c a d=r j$ a\&uact $=8 \& v e d=2$ ahUKEwiZgYe84 qAhVO6XMBHa_UA2EQFjABegQIAxAB\&url=http $\% 3 \mathrm{~A} \% 2 \mathrm{~F} \% 2 \mathrm{Flink}-$ springer-com-443.webvpn.fimu.edu.cn\%2Fchapter\%2F10.1007\%252F978-981-106926-0 2\&usg=AOvVaw0Rufr6uEgTfdtD0EE83BsD

Saridona, R. \& Cahyandito, M. F. (2015). Social Performance of Indonesia Islamic Banking: Analysis of Islamic Social Reporting Index. Proceedings of the International Conference on Economics and Banking 2015. https:/ /dx.doi.org/10.2991/iceb-15.2015.29 
Islamic Social Report, Corporate Governance Strength, and Industry Characteristics ...

Siwar, C., \& Hossain, T. (2009). An analysis of Islamic CSR concept and the opinions of Malaysian managers. Management of Environmental Quality, 20(3), 290-298. https://doi.org/10.1108/14777830910950685

Sofyani, H, Ulum, I., Syam, D., \& Wahyuni, S. (2012) Islamic Social Reporting Index Sebagai Model Pengukuran Kinerja Sosial Perbankan Syariah (Studi Komparasi Indonesia dan Malaysia), Jumal Dinamika Akuntansi, 4(1), 36-46. https://doi.org/10.15294/jda.v4i1.1958

Sofyani, H. (2014). Islamic Social Reporting Perbankan Syariah di Indonesia, Malaysia dan Saudi Arabia: Sebuah Studi Menggunakan Anova. Summary Research, Fakultas Ekonomika dan Bisnis. Universitas Gadjah Mada, Yogyakarta.

Sulaiman, M., \& Willett, R. J. (2003). Using the Hofstede-Gray framework to argue normatively for an extension of Islamic Corporate Reports. Malaysian Accounting Review, 2(1), 81-105. http://dx.doi.org/10.24191/mar.v2i1.535

Sulistyawati, A. \& Yuliani, I. (2017). Pengungkapan Islamic Social Reporting Pada Indeks Saham Syariah Indonesia. AKUISISI, Journal of Accosaktiunting \& Finance. 13(2), 15-27

Suwaldiman. (2013). Motivasi Pelaporan Kinerja Sosial/Lingkungan (Triple-Bottom-Line Reporting): Sebuah Tinjauan Teoritik. EKBISI, 8(1), 65-74. Retrieved from https: / www.google.com/url? sa $=$ t\&rct $=$ i\&q $=\& e s r c=$ s\&source $=$ web\&cd $=\& c a d=r i$ a\&uact $=8 \& v e d=2$ ahUKEwiY6a s7 ipAhVimuYKHRCSBUQFjAAegQIBhAB\&url=http $\% 3 \mathrm{~A} \% 2 \mathrm{~F} \% 2 \mathrm{Fejournal.uin}$ suka.ac.id $\% 2$ Fsyariah $\% 2$ FEkbisi $\% 2$ Farticle $\% 2$ Fdownload $\% 2 F 347 \% 2 \mathrm{~F} 322 \& u s g=A$ OvVaw2C-py0PIN2iggbtQG KCDW

Umbara, D. M. B., \& Suryanawa, I. K. (2014). Pengaruh pengungkapan tanggung jawab Sosial pada nilai perusahaan. E-Jurnal Akuntansi, 9(2), 410-424. Retrieved from https://ojs.unud.ac.id/index.php/Akuntansi/article/view/9159

Wan Abdullah, W. A., Percy, M., \& Stewart, J. (2014). Corporate Governance Disclosure Practices of Islamic banks: the Case of Islamic banks in the Southeast Asian and the Gulf Cooperation Council region. Journal of International Accounting Research (JLAR) Conference.

Widiawati, S., \& Raharja, S. (2012). Analisis Faktor-Faktor Yang Mempengaruhi Islamic Social Reporting Perusahaan - Perusahaan Yang Terdapat Pada Daftar Efek Syariah Tahun 2009-2011. Diponegoro Journal of Accounting, 1(2), 248-262. Retrieved from https:/ $/$ www.google.co.id/url?sa $=$ t\&rct=j\&q $=\& e s r c=s \&$ source $=$ web\&cd $=\& c a d=r j$ a\&uact $=8 \&$ ved $=2$ ahUKEwifuoP2-

4 qAhWTYysKHfovBkkQFjAAegQIBRAB\&url=https $\% 3 \mathrm{~A} \% 2 \mathrm{~F} \% 2 \mathrm{Fejournal} 3$.und ip.ac.id $\% 2$ Findex.php $\% 2$ Faccounting $\% 2$ Farticle $\% 2$ Fview $\% 2$ F $482 \& u s g=A O v V a w 0$ BiPCq61-lmuktuUoF2FCH

Widiyanti, N. W \& Hasanah, N. T. (2017). Analisis Determinan Pengungkapan Islamic Social Reporting (ISR). Jurnal Bisnis dan Manajemen, 5(2), 239-264.

http://dx.doi.org/10.21043/bisnis.v5i2.3013

Yusuf, M. Y. (2017). Islamic Corporate Social Responsibility (I-CSR). Jakarta: Kencana.

Zubairu, U. M., Sakariyau, O. B., \& Dauda, C. K. (2011). Social reporting practices of Islamic banks in Saudi Arabia. International Journal of Business and Social Science, 2(23). 193-205.

Retrieved from https: $/ /$ www.google.com/url? sa $=t \& r c t=j \& q=\& e s r c=s \&$ source $=w e b \& c d=\& c a d=r j a$ $\underline{\text { \&uact }=8 \& v e d=2 \mathrm{ahUKEwiC78v28fjpAhUIlEsFHTCTBzkQFjAAegQIAhAB \& url}=\mathrm{h}}$ ttp $\% 3 \mathrm{~A} \% 2 \mathrm{~F} \% 2 \mathrm{Fwww} . \mathrm{ijbssnet.com} \% 2 \mathrm{Fjournals} \% 2 \mathrm{FVol} \_2$ No 23 Special_Issue D D ecember_2011\%2F23.pdf\&usg=AOvVaw3kCsQVDPNv_vQ6PGamw88M 